\title{
The Kurdish Files of Saddam Hussein's Ba'ath Regime: Struggle for Reconciliation in Iraq
}

\author{
Bruce P. Montgomery ${ }^{1}$, Ferdinand Hennerbichler ${ }^{2}$ \\ ${ }^{1}$ Former Professor/Director of Archives and Iraq Documents Initiative, University of Colorado Boulder, Boulder, CO, USA \\ ${ }^{2}$ Department of History, College of Humanities, University of Sulaimani (UoS), Sulaymaniyah, Kurdistan Region Iraq \\ Email: `brucemontgomery1955@gmail.com, ferdinand.hennerbichler@univsul.edu.iq
}

How to cite this paper: Montgomery, B. P., \& Hennerbichler, F. (2020). The Kurdish Files of Saddam Hussein's Ba'ath Regime: Struggle for Reconciliation in Iraq. Advances in Anthropology, 10, 181-213. https://doi.org/10.4236/aa.2020.103011

Received: May 7, 2020

Accepted: June 30, 2020

Published: July 3, 2020

Copyright $\odot 2020$ by author(s) and Scientific Research Publishing Inc. This work is licensed under the Creative Commons Attribution International License (CC BY 4.0).

http://creativecommons.org/licenses/by/4.0/ (c) (i) Open Access

\begin{abstract}
The U.S.-led wars against Iraq in 1991 and 2003 resulted in the seizure of vast quantities of internal state security documents from the former regime of Saddam Hussein. Following Iraq's 1991 defeat in Kuwait, the Kurds staged a popular uprising against Saddam's dictatorial rule, capturing tons of secret police files that detailed vast humanitarian crimes, including corroborating evidence of the "al-Anfäl" (referring to Quran: "The Spoils of War") genocide, against the Kurds in the late 1980s. These files were transferred to the U.S. where they were digitized and analyzed for a possible genocide case against the Saddam regime. Another estimated 120 million pages of documents were seized by U.S. forces in the 2003 war in the failed hunt for evidence of Saddam's alleged unconventional weapons and ties to al Qaeda. Most of the seized Ba'athist records, along with digital copies of the Anfāl files, have since been returned to Baghdad and various parties in Iraqi Kurdistan. The state security files of Saddam's regime hold considerable historical importance and value for the peoples of Iraq. The documentary legacy of Saddam's Ba'ath regime should be used to help Iraqis come to terms with their tragic history and initiate sweeping democratic reforms on behalf of reconciliation and the rule of law. This has proved difficult to achieve. Corruption and the cycle of revenge in both Baghdad and Erbil have fueled the increased exploitation and weaponization of these state security records against political and sectarian rivals. In Baghdad, the sectarian misuse of the files has helped to fuel new waves of still escalating tensions, confrontations, and the continuing destabilization of Iraq. The Kurdish political parties also have exploited the Anfāl files against their political adversaries, raising the specter of new infighting, division, civil war, and the continued supplication to foreign influence. Nonetheless, several positive and countervailing developments have fostered greater access to these documents in digital form among Iraqi Kurds in the hope of promoting human rights, the rule of law, and learning from
\end{abstract}


Iraq's recent history under Saddam's homicidal regime. This article explores these topics in detail, including the seizure and restitution of the records, the political and sectarian misuse of the files, and the recent positive trends that hold the possibility of using the files in the spirit of human rights and the rule of law in Iraq and the Kurdistan Region. It also outlines a number of concrete steps that Iraq's political leaders can take to reinforce these positive trends with the help of international supporters.

\section{Keywords}

Kurds, Iraq, Saddam Hussein's Ba'ath Regime, "al-Anfāl”, Kurdish Genocide, "Amna Suraka" ("The Red Security") Former Secret Police Torture Center Sulaimaniyah, U.S.-Digitalized Documents, Restitution to Iraq and to the Iraqi Kurds, Reconciliation

\section{Introduction}

In May 2013, the U.S. discreetly repatriated more than 120 million pages of records and archives, seized in the 2003 war, into the hands of Iraq's security services under Nouri al-Maliki, the sectarian-driven premiere of the majority Shiite government. U.S. forces had captured the Saddam regime's records and archives in the hunt for unconventional weapons and ties to Al-Qaeda, the erroneous rationale for invading Iraq. The Pentagon returned the documents after exhausting their utility for intelligence-finding no evidence of unconventional weapons and after withdrawing its troops from Iraq in 2011. The restitution of the Saddam regime records and archives to Maliki's security services augured their sectarian exploitation against the Sunni elites of the former Ba'athist regime.

Approximately a year and a half later in October 2014, a high-level delegation from Iraqi Kurdistan visited the University of Colorado at Boulder (CU-Boulder) to receive a digital copy of the Anfāl genocide files held by the University's former Human Rights Archives. In an official restitution ceremony, the University's Chancellor handed a hard drive of the files to a three member Kurdish delegation representing the Kurdish Regional Government (KRG) and the Zheen Archive Center in Sulaimaniyah. The delegation was accompanied by Ferdinand Hennerbichler, Professor of History at the University of Sulaimaniyah and former Austrian diplomat, who negotiated the repatriation of the digital files with Professor and Director of Archives and founding director of the Iraq Documents Initiative, Bruce P. Montgomery (Hennerbichler \& Montgomery, 2015). The repatriation of the digital Anfāl files to Iraqi Kurdistan was more than symbolic, representing a return of Kurdish patrimony detailing one of the most significant and tragic events in Kurdish history. Nor did their restitution signal an end to the extraordinary events surrounding the journey of the original 18-metric tons of files since their initial seizure in the March 1991 Kurdish uprising. Indeed, the Kurds continue to seek the return of the original paper Anfāl documents, cur- 
rently housed at the Special Tribunal in Baghdad under the control of the majority Shiite government.

This article examines the seizure and repatriation of the Saddam regime records and archives stemming from the 1991 Kurdish uprising and the 2003 U.S.-led invasion of Iraq and the socio-political consequences of their restitution to Iraqi Kurdistan and the Federal Republic of Iraq. It explores how various players have used or misused the documents against the best interests of the country and suggests ways to employ these archives of atrocity for reconciliation. The article relies on various print and digital primary and secondary sources, discussions and correspondence with scholars and Kurdish sources in Iraqi Kurdistan and abroad, and the personal involvement of the authors in key events regarding the acquisition of the original paper and digital Anfāl files and their return to the Kurdistan Region of Iraq and Special Tribunal in Baghdad for use in the Anfāl trials of Saddam Hussein and his top lieutenants.

The relationship between the original paper Anfāl files and the digital database to these documents merits clarification. After the Kurds seized the original Anfäl files in the 1991 uprising, three Kurdish parities holding the documents agreed to transfer them to the U.S. for safe storage and analysis for a possible genocide case against Saddam's Ba'athist regime. The transfer agreements with the three Kurdish parties in 1992 and 1993 recognized their respective ownership over the documents. The U.S. Defense Intelligence Agency (DIA) digitized the Anfāl files, while the originals were entrusted to the National Archives for storage. Both the original documents and a copy of the digital Anfāl files were transferred and provided to CU-Boulder's Human Rights Archives in early 1998. In 2005, the original Anfāl documents were turned over to the U.S. Justice Department's Crimes Liaison Task Force, which sent them to the Special Tribunal in Baghdad for the Anfāl trials of Saddam and several of his top lieutenants. CU-Boulder provided a copy of the digital Anfāl files to a visiting Iraqi Kurdish delegation in 2014. With the exception of a small cache of documents that were returned to the Kurds in 2019, the majority of the original Anfäl files still reside at the Tribunal in Baghdad in the custody of the Shiite majority government. Although these documents constitute Kurdish patrimony, their ultimate fate remains undetermined.

\section{Background}

In March 1991, after Iraq's defeat in the First Gulf War, the Kurds staged a rebellion for liberation against Saddam Hussein's regime. In the uprising, more than 18 metric tons of secret police files were seized from Iraq's security agencies from the three Kurdish governorates across northern Iraq, primarily from $\mathrm{Su}$ laimaniyah but also from Dohuk and Erbil. The Kurdish peshmerga spirited away the secret police files to remote hideouts before Saddam's security forces could subdue the uprising, sending more than a million Kurds in desperate flight to the border regions of Iran and Turkey. The Kurd's plight induced the U.S. 
and its allies to establish a no-fly zone over Iraqi Kurdistan to enable the refugees to return to their homes and ward off further Iraqi attacks. The Kurds' initial interest in the documents lay in determining the identities of informants working for Iraqi intelligence. But they soon realized their larger significance in containing evidence about the Anfāl genocide, which ended two years earlier (Human Rights Watch, 1994; Montgomery, 2001). The Anfäl comprised the genocidal apex of a military campaign between 1987 and 1989 to punish the Kurds for allying with Iran in the Iran-Iraq war and their decades-long resistance against the Iraqi state. What began as a counter insurgency operation to restore control over northern Iraq rapidly escalated into a series of war crimes, crimes against humanity, and genocide.

News of the captured documents attracted the attention of Peter Galbraith, a staffer and Iraq specialist at the U.S. Senate Foreign Relations Committee who visited Iraqi Kurdistan in March and April 1991 to survey the Kurdish situation. While in northern Iraq, Jalal Talibani, the late leader of the Patriotic Union of Kurdistan (PUK), informed Galbraith that his resistance fighters possessed tons of secret police files seized in the first hours of the revolt (Galbraith, 2002). Many other captured files were held by Masoud Barzani's Kurdish Democratic Party (KDP) and the Kurdish Socialist Party of Dr. Mahmoud Osman (Galbraith, 1992: p. 1 and 7). ${ }^{1}$ The documents, which chronicled the systematic razing of villages and the torture and murder of tens of thousands of Kurds, offered the unprecedented opportunity of prosecuting the Iraqi leadership under the 1948 United Nations Convention on Genocide. Together, the files constituted the largest body of war crimes evidence since the Allies captured the German files in World War II (Montgomery, 2001, 2011, 2014; Human Rights Watch, 1994).

Andrew Whitely, Middle East director at Human Rights Watch (HRW), also learned of the captured documents and offered to analyze them to build a possible genocide case against the Iraqi regime. With the support of the Senate Foreign Relations Committee and Secretary of Defense Dick Cheney, Galbraith received authorization to negotiate their transfer to the U.S. for safe storage and analysis. The PUK agreed to transfer its share of the files to the U.S. in 1992 on the basis that they would remain its property. These same terms governed the transfer agreements with the KDP, the PUK and the Osman's Kurdish Socialist Party ${ }^{2}$ - these files arrived in the U.S. in 1993. Once on American soil, the Senate Foreign Relations Committee assumed legal custody of the files and entrusted them to the U.S. National Archives and Records Administration, which housed ${ }^{1}$ Summing up Gailbraith, 1992: p. 1 wrote: "During this trip, I was able to arrange for the delivery to the U.S. forces in Northern Iraq of forty cubic meters of captured documents. This represents al the documents held by Talabanis party, the Patriotic Union of Kurdistan. In addition, I received a commitment from the Socialist Party to turn over another cache, perhaps ten cubic meters, immediately. Finally, Massoud Barzani agreed to turn over his documents after his party, the Kurdish Democratic Party, has had a chance to review and duplicate them. The KDP documents, according to Barzani, are larger than any other set."

${ }^{2}$ According to Peter W. Galbraith, 1992: pp. 1 and 7, the [Kurdish] Socialist Party of Dr. Mahmoud Osman (on page 7 the name is misspelled "Osmon") committed itself "to turn over immediately" circa 10 cubic meters of documents. 
them at a branch facility in Maryland (Gellman \& Randal, 1992; Horn, 1992; Montgomery, 2019).

An unusual partnership ensued between HRW and the U.S. Defense Intelligence Agency (DIA), which offered logistical support in reading, processing, and scanning the millions pages of documents. The arduous task of classifying, scanning, and analyzing so much material, with the urgency of HRW's goal of preparing a genocide case against the Iraqi regime, was beyond the human rights group's capabilities. HRW accepted the DIA's offer of logistical assistance on terms that its documents analysis unit would work under its direction. Based on extensive interviews of survivors and victims, exhumation of mass graves, and analysis of the documents from 1992 to 1994, HRW concluded that Saddam's regime was guilty of grave humanitarian crimes, including genocide (Montgomery, 2001, 2011, 2014; Human Rights Watch, 1994).

Following the conclusion of the HRW/DIA research project, the Senate Foreign Relations Committee approved the transfer of the 18 metric tons of captured secret police files to CU-Boulder's Human Rights Archives. The DIA also provided the Archives a copy of the digital files to the collection on $176 \mathrm{CD}$ ROMs in early 1998. Professor and Archives Director Bruce P. Montgomery subsequently founded the Iraq Documents Initiative (IDI) to promote and make accessible the trove of captured Iraqi secret police files and the digital database to U.S.-based and international researchers. The Senate Committee's January 1998 letter of transfer noted that the Kurdish parties had the right to demand the return of the files. At the time, Saddam Hussein was still firmly in power and the prospect of their return to Iraqi Kurdistan seemed impossibly remote (Montgomery, 2001).

In the 1990s, the original files at CU-Boulder attracted the attention of the State Department's then war crimes office and INDICT, an international human rights group that sought to bring Saddam and his henchmen before an international tribunal like Nuremberg. INDICT investigators visited CU-Boulder to consult Montgomery and the secret police files. INDICT found a Belgium court willing to review the evidence with the aim of possibly bringing indictments against the Iraqi leadership. HRW had pursued a different approach, preparing detailed dossiers of evidence to enlist several governments in bringing a genocide case against Iraq under the 1948 Genocide Convention. Nevertheless, these attempts failed due to the lack of political will in the international community, which proved more inclined to rely on the UN sanctions against Iraq (Hiltermann, 2000; Montgomery, 2019).

\section{Return of the Original and Digital Anfāl Files}

These developments were overtaken by the 2003 U.S.-led invasion of Iraq, resulting in the capture of Saddam Hussein and his key lieutenants who were turned over for trial before an Iraqi special tribunal. The U.S. Justice Department formed the Regime Crimes Liaison Task Force to assist the tribunal in ga- 
thering and cataloguing evidence for the court proceedings. In December 2004, Montgomery turned over the original 18 metric tons of secret police documents seized by the Kurds in the March 1991 uprising to the Task Force, which sent them to Baghdad for the trials. Montgomery's Iraq Documents Initiative retained the digital copy of the files, promoting their use for research subject to access protocols that ensured the confidentiality and protection of individuals named in the files (Montgomery, 2019).

In August 2006, with the Anfäl files and other evidence housed at the Special Tribunal in Baghdad, Saddam and several other defendants including his first cousin, Ali Hassan al-Majid, the overlord of the Anfāl genocide, stood trial for their humanitarian crimes against the Kurds. Nonetheless, in December 2006, the Iraqi Shiite Premier, Nouri al-Maliki, interrupted the Anfāl proceedings and rushed Saddam to the gallows after his conviction for another crime-the 1982 massacre of 148 Shiite men and boys in the village of Dujail in retaliation for an attempted assassination of Saddam. The tribunal dropped the charges against Saddam after his execution and convicted and sentenced to death Majid and two co-defendants in June 2007. Following his appeal, Majid was executed in June 2010. (Bennet, 2006; Raghaven, 2006; Galbraith, 2007; Chatham House, 2008). Following the genocide trials, the Anfäl documents remained at the tribunal in Baghdad, in the control of the majority Shiite regime, beyond the reach of the Kurds.

Several years later, on September 30, 2014, the Chancellor of CU-Boulder hosted a restitution ceremony, handing over an external hard drive of the Anfāl genocide files to a high-level delegation from Iraqi Kurdistan. The restitution ceremony was the culmination of two years of negotiations between Professors Montgomery and Hennerbichler, who mediated the repatriation agreement between CU Boulder and Iraqi Kurdish officials. Joining the repatriation event via Skype was Dr. Barham A. Salih, Iraq's current President who played a central role in arranging the transfer of the original captured Anfāl files to the U.S. in 1992 and 1993 for safe storage and analysis. Salih said that the repatriation of the files was personally an extraordinarily important event given what the files revealed and his role in mediating their relocation to the U.S. for purposes of bringing a possible genocide case against Saddam's regime (Hennerbichler \& Montgomery, 2015).

Other members of the delegation believed that the digital files would enable Iraqi Kurdistan to come to terms with its history. Ako M. Wahbi, a leading businessman and international representative of the Zheen Archive Center in Sulaimaniyah, stated that the files would be critically important in informing the Kurdish people of their history under Saddam Hussein's regime. Another member of the delegation, Woshiar Rasul Mohammed Amin of the Sulaimaniyah Governorate, echoed Ako Wahbi's statement that the restitution of the digital files represented a historic moment. The U.S. not only had liberated the Kurds from Saddam's dictatorship in 2003, he said, but was now returning important historical documents to Kurdistan which would have positive consequences for the Kurds in revealing the tragic events that befell Iraqi Kurdistan 
(Hennerbichler \& Montgomery, 2015).

Following the repatriation ceremony, the Zheen Archives Center and the CU-Boulder Archives began planning a series of joint projects aimed at expanding the collection, preservation, and global availability of Kurdistan's documentary history. Professor Montgomery subsequently visited Iraqi Kurdistan in fall 2016 at the invitation of Kurdish representatives and Professor Hennerbichler to discuss these cooperative projects in greater detail. Nevertheless, the rise of ISIS which had overrun large swaths of territory in Iraq and other events intervened. Montgomery also left his position soon after CU-Boulder divested itself of the digital files chronicling the Kurdish genocide, sending the Anfāl database to the U.S. Senate Foreign Relations Committee in late 2016.

The expunging of the Anfäl digital files ended CU-Boulder's highly successful twenty-year project that both acquired an exceedingly rare collection of internal, incriminating files of a totalitarian regime still in power and opening these files for research, publicly exposing its humanitarian crimes to the world. The only comparable example involving the acquisition of an internal archive of a totalitarian regime still in power was the Smolensk archive, seized by Nazi troops from Odessa in Germany's invasion of the Soviet Union in 1941 (Sassoon \& Brill, 2020). The archive was seized again by U.S. troops in Bavaria in 1945, providing historians the unique chance to study the internal conflicts within the Soviet one-party state. The Smolensk archive was microfilmed by the U.S. National Archives, which provided a copy to Harvard University.

CU-Boulder's elimination of the Anfāl digital archive followed the unrelated closing of the Pentagon's Conflict Records Research Center (CRRC) in 2015 due to funding cuts. The U.S. Defense Department created the CRRC as a digital public archive in 2010 at the National Defense University in Washington D.C. with the aim of promoting academic research into the millions of documents captured from Saddam's regime in the 2003 invasion of Iraq. U.S. forces had seized the internal records of Ba'athist Iraq in the hunt for evidence of weapons of mass destruction and ties to al-Qaeda-the erroneous rationale for the Iraq war. The documents were analyzed in the field for perishable intelligence, then transferred to a media processing facility in Qatar where they were digitized and uploaded into the intelligence community's shared Harmony database for further analysis (Gordon, 2015; Montgomery \& Brill, 2019).

The CRRC provided researchers access to declassified copies of digitized records seized in the 2003 Iraq war as well as in the fight against Islamic extremism in Iraq and Afghanistan. Before its termination, the CRRC was attracting researchers from around the world to study Saddam's Ba'athist regime, the rise of Islamic extremism, and the wider Middle East. Two years earlier, federal budget cuts also impelled the Pentagon to unload the millions of seized Saddam regime records from the 2003 war and repatriate them-without a copy of the digital database - to the sectarian-driven, Shiite majority regime of prime minister Nouri al-Maliki. On May 16, 2013, the U.S. Defense Department discreetly 
shipped the documents by sea from its storage facility in Qatar into the hands of Maliki's national security adviser, Falih al-Fayyad, and his pro-Iranian security services. As a high-level official in Iraq's national security apparatus, Fayyad led the repatriation talks with the U.S. State Department, signaling Baghdad's acute interest in the files. There are strong indications that the delivery of the documents to Fayyad-listing thousands of former Ba'athist intelligence and security personnel, as well as collaborators and informers-provided an exploitable trove of intelligence to the majority Shiite regime for the sectarian purges of Sunni elites from power (Montgomery, 2019).

The closing of the CU-Boulder and CRRC projects left only the Hoover Institution at Stanford University to provide access to captured Iraqi documents-including several databases comprising materials taken in conflicts involving the first Gulf War, the 1991 Kurdish uprising, and the 2003 U.S.-led invasion of Iraq. These collections had been deposited at Hoover by Kanan Makiya, founder of the Iraq Memory Foundation (IMF). Following the 1991 Gulf War, Makiya, the Iraqi dissident and then Professor of Middle East Studies at Brandeis University, also began collecting documents from Saddam Hussein's regime. In the 1990s, he obtained digital copies of documents seized by U.S. forces in Kuwait in the First Gulf War. He further acquired a copy of the digital Anfäl files-calling them the North Iraq Data Set-from the Senate Foreign Relations Committee in late 1998 (Sassoon \& Brill, 2020). The database received by Makiya, however, may be an abridged version, comprising an estimated 2.4 million pages rather than the 5.5 million-page database acquired months earlier by CU-Boulder.

Moreover, with the 2003 U.S.-led invasion of Iraq, Makiya formed the IMF as a registered military contractor and entered Iraq to preserve Saddam's archives of atrocity with plans of building a memorial center in the heart of Baghdad's Green Zone and exposing Iraqis to their totalitarian past. The IMF assumed custody of nearly 7 million pages of Ba'ath Party records, but Iraq's sectarian civil war and insurrection against the U.S. occupation led Makiya to abandon the project. He subsequently convinced the Pentagon to transport the archive to the U.S. for analysis of the Sunni insurgency. The DIA digitized the files and returned and provided both the originals and a copy of the database to Makiya who then deposited them, along with the other collections, at the Hoover Institution (Montgomery, 2014, 2019). Hoover now grants access to these records and archives according to standard archival procedures. ${ }^{3}$ Hoover has opened an office in Washington, D.C. in proximity to the U.S. intelligence agencies, the Pentagon, the State Department, and other major research universities to foster greater research use of their Iraq collections. Hoover currently stores the multi-million-page Ba'ath Party collection at an off-site facility in California but will soon be turning the archive over to the U.S. government for repatriation. ${ }^{4}$

${ }^{3}$ https://oac.cdlib.org/AccessAgreement_HIZB final.pdf (not available at the time of retrieving, the $26^{\text {th }}$ of Nov. 2019).

${ }^{4}$ https://oac.cdlib.org/findaid/ark:/13030/c84j0cg3/entire_text/ (retrieved 26 November 2019). 
Following his departure from CU-Boulder, Montgomery received word from an international human rights official that the University was still holding 52 boxes of original Iraqi secret police files at an off-campus storage facility. These boxes were overlooked by University personnel in turning over the 18 metric tons of documents to the Crimes Liaison Task Force for use in the Anfäl trials of Saddam, Majid, and others. Montgomery relayed this information to Ako Wahbi and Professor Hennerbichler who subsequently became entangled in lengthy logistical negotiations with the university to retrieve the files, which finally arrived in Iraqi Kurdistan in June 2019. The retrieval of these documents accorded with the January 1998 letter from the U.S. Senate Foreign Relations Committee, stating that the Iraqi Kurds owned the documents and that any request by them for their return must be honored (Montgomery, 2019).

The ultimate fate of the original 18 metric tons of Anfāl files, currently housed at the tribunal in Baghdad, remains unknown. The documents were defined as Kurdish patrimony under the original transfer agreements that provided for their removal to the U.S. in the early 1990s for safe storage and analysis of Saddam's humanitarian crimes. The documents, however, now provide a unique opportunity for Baghdad to restore them to Iraqi Kurdistan as a gesture of good will, reconciliation, and recognition of Kurdish suffering under Saddam's regime. Returning the documents would constitute an important acknowledgement of the Anfāl genocide-an acknowledgement that the world community has insufficiently provided. U.S. diplomats and others in Baghdad should encourage the Iraqi government to do so with the aim of promoting the reconciliation of Iraqi society, which has suffered grievously from sectarian schism and civil war.

In the U.S., the vast majority of the documentary history of Saddam Hussein's regime is in digital form and remains classified and buried in the Pentagon's Harmony database. The CRRC's mission of providing digital access to these documents proved remarkably successful for a brief five years before its termination in 2015. Professor Montgomery was able to provide copies of some of these historical documents relating to Kurdish affairs to Professor Hennerbichler who then passed them on to authorized Kurdish officials. It is reasonable to assume that the Pentagon's trove of digitized captured documents-yet to be declassified-from the 2003 Iraq war include many more files chronicling Saddam's repressive policies governing Iraqi Kurdistan.

Nonetheless, there are calls to revive the CRRC and transfer its work to a U.S. civilian research institution or university to continue its work. If this occurs, the opportunity could arise for Kurdish scholars and government officials to form a cooperative project with the CRRC's public digital archive to derive declassified and translated releases of documents pertaining to Iraqi Kurdistan. Such an initiative would foster Kurdish and international study and research of Kurdish history. It would open up rare and major source materials from a former totalitarian regime and promote international understanding of the Kurdish situation. 


\section{Legal Status of the Anfāl and Ba'ath Regime Files}

The legal status of both the Anfāl files, seized in the 1991 Kurdish uprising, and the Saddam regime files, captured in the 2003 war, have been in dispute for an extended period of time, entangled in the politics over the U.S.-led invasion of Iraq. Nevertheless, consensus has emerged among scholars, diplomats, politicians, and archivists that both archival collections belong to the respective democratic "peoples" of Kurdistan and Iraq. The Kurdish Anfāl files rightfully belong to the "Kurdish people of Iraq" (US Foreign Senate Relations Committee, 1998; Montgomery, 2010; Human Rights Watch, 1993), while the former Saddam regime records belong to "the people of Iraq" (Wilkinson, 2019: p. 8/21: "widespread agreement"). The legitimate representatives of the "peoples of Iraq" constitute the democratically elected deputies of the Council of Representatives of the Federal Republic of Iraq in Baghdad. The "Kurdish people of Iraq" are represented both by elected Kurdish members of the central Parliament in Baghdad and by incumbent lawmakers of the Kurdistan Regional Parliament in Erbil. Given these circumstances, the legitimate will of the "Kurdish people of Iraq" is expressed by the democratically elected majority in the Parliament of the Kurdistan region in Iraq, in cooperation with the Council of Representatives in Baghdad-both act within the common rule of law of Iraq's 2005 Federal constitution.

In January 2008, the Council of Representatives in Baghdad passed the "Accountability and Justice Law." ${ }^{5}$ Under chapter 3, Art. 4, Fifth, b, the law provides that, "All files of the dissolved Ba'ath Party shall be transferred to the Government in order to be kept until a permanent Iraqi archive is established pursuant ${ }^{5}$ Law No. 10 of 2008, Supreme National Commission of Accountability and Justice, passed January 12, 2008, by the Council of Representatives in Baghdad with 140 out of 275 lawmakers being present. Vice President Tariq al-Hashimi refused to sign the law. It was passed by the Presidency Council by a majority vote under the Transitional Administrative Law (TAL). Iraq law collection see: http://gipi.org/wp-content/uploads/gazette-index-2008.htm (retrieved 26 Nov. 2019). Reactions: The International Centre for Transitional Justice (ICTJ) in New York called the law "not the major change that reformers had hoped. [...] The law also preserves the controversial Higher National De-Ba'athification Commission (HNDBC) [...]. Some positive changes have been made, however, mainly to do with clarification of pension rights and the level of membership at which dismissal and reinstatement procedures are to be applied. One other major development is a new requirement to dismiss some former employees of Iraq's notorious intelligence and security agencies from government service." See ICTJ Briefing Paper, 22.01.2008, p. 2:

https://www.ictj.org/publication/unofficial-translation-iraqs-accountability-and-justice-law (retrieved 26 Nov. 2019).For unofficial translation of the law, see:

IraqGovt-Iraq-Translation-Law-2008-English.pdf (retrieved 26 Nov. 2019). Feisal Amin al-Istrabadi, Iraqi lawyer, former diplomat and in 2004 one of the main drafters of Iraq's Transitional Administrative Law (TAL), welcomed the law in correcting the over-regulations of L. Paul Bremer's (head of the Coalition Provisional Authority 2003-2004) original De-Ba'athification decrees (CPA order 1, 16 May 2003). Al-Istrabadi: They "captured a large number of people who were innocent of any wrongdoing by any objective measure and were deprived of the ability to earn a living and support their families"; triggering insurgencies. Background: The majority of Ba'ath members were Shia, but Sunnis were disproportionally removed from positions, a process later called "de-Sunnification" of Iraq. See Foreign Policy, "Seven Questions: The De-Bremerification of Iraq," January 16, 2008, https://foreignpolicy.com/2008/01/16/seven-questions-the-de-bremerification-of-iraq/ (retrieved 26 Nov. 2019). Further reading: Ghanim, David (2011). De-Ba'athification and Politics of Exclusion. Iraq's Dysfunctional Democracy. Santa Barbara/Dnver/Oxford: Praeger, p. 55 cf. 
to the law" (Montgomery, 2011: p. 328; Wilkinson, 2019: p. 7/21). As a result, since January 2008, the Iraqi government in Baghdad has been obligated under law to act as custodian of the former Ba'ath party's files until "a permanent Iraqi archive" is established. The law provides no time limit when such an archival institution should be established, leaving this obligation currently unfulfilled. Even so, the federal legal provision for establishing a special, independent institution responsible for the former files of Saddam Hussein's Ba'ath Regime could also be seen as precedence to create such an archival institution for the Kurdish Anfāl files in the Kurdistan Region.

In Sulaimaniyah, the cultural capital in the southeast Kurdistan Region of Iraq, the Kurds have preserved one of the Saddam regime's most cruel interrogation and torture centers-the "House of Horror" (in Kurdish: "Amma Suraka," Red Security). For Iraqi Kurds, the "House of Horror" stands as a grim, Stalin-like, gulag complex, a symbol of their decades-long repression under Saddam's sadistic and genocidal rule. Since the Saddam regime's demise, the former "House of Horror" is being converted into a Kurdish memorial museum with the aim of also creating a genocide and human rights center. The project's concept was developed by Ako Ghareeb, a leading Iraqi Kurdish painter, culture manager, and media creator. The new museum and human rights center could serve as the permanent home for the digital and original Anfāl files, but the Kurdistan Regional parliament would have to designate it as the official repository for the documents. In the interim, the digital files are under the temporary custodianship of the Zheen (Life) Archive Center in Sulaimaniyah, acting on behalf of the legitimate representatives of the Iraqi Kurds. The Zheen Center will continue to act in this capacity until the Kurdistan Regional Parliament in Erbil passes regulations governing access to the files and possibly establishes an independent institution to house and administer the documents-both the digital database and the originals.

There are international guidelines that should inform the legalities of regulating access to both the Kurdish Anfāl files and the Saddam regime's Ba'athist records, although it remains unclear how they would be implemented and applied in Iraq. Both collections comprise numerous sensitive files relating to former Ba'athist officials, secret police and intelligence agents, informers and collaborators, as well as lists of other names. Providing unregulated, public access to these files poses significant risks of their misuse for retribution, personal and political blackmail, false trials and convictions, or revenge killings-subverting the rule of law and social and political stability in Iraq.

The fundamental principle of presuming one's innocence until proven guilty after a fair trial in an independent court has direct applicability in this matter. There is general consensus that these state security files, which document the crimes of the former Ba'athist regime, should only be used in accordance with the rule of law and with the permission of the relevant government ministries that oversee the files on behalf of the people of Iraq and the Kurdistan region. 
Nonetheless, even in cases when a country has no existing laws regulating access and use of a predecessor regime's state security files, basic constitutional principles of jurisprudence that presume the innocence of the accused unless convicted by an independent court should apply. This principle represents a basic standard of jurisprudence long accepted by constitutional democracies.

The legal governance of the country's state records dates to 1961 when the Iraqi Republic (1958-1968) under the military junta of Army brigadier Abd al-Karim Qasim (1914-1963) established a National Library (Archive and Library) in Baghdad. Under the one-party state, Iraq's legislature, the Revolutionary Council, enacted law 51 on August 9, 1961, forming the legal basis for modern archiving in Iraq. Art.1 set out the law's main purpose involving collecting and preserving Iraq's cultural property and making it available for public research. Iraq's national library and archive, however, held scarce relevance for Iraq's Kurds who were considered by successive Iraqi autocratic regimes as little more than an internal enemy presence. If the preservation of Kurdish heritage were ever going to happen, the Kurds would have to do it themselves.

More than 50 years later, in 2014, after the Kurds had won quasi-independence in the turbulent post-Saddam Iraq, the Kurds attempted to pass an archiving law aimed at safeguarding their history. The Parliament of the Kurdistan Region of Iraq passed a Documents Safe-keeping law after a first reading of the proposed legislation. Drafted and signed primarily by Parliamentarians of the "Gorran" (Change) movement, the law received a majority vote in the Parliament upon its first reading on November 11, 2014. Art. 1 of the law provided for establishing a "Center" (institution) under the Council of Ministers of the Kurdistan Regional Government (KRG). Art 10 enabled access to archival data according to the following criteria: a) that such data would be made accessible after 20 years providing that it did not violate the "rights of citizens" and that government records would be made available after 30 years; b) that medical research records would be accessible 60 years after the birth of an individual; and c) that other information would be made publicly accessible without limitation. Nevertheless, the Kurdish parliament denied giving the law a second as well as third and final reading, failing to pass the legislation.

In Baghdad, however, the Council of Representatives of the federal parliament of the Republic of Iraq adopted a Documentation Safe-keeping law on December 19, 2016. Art. 1 of the law covers documentation entailing academic, historic, and administrative "importance." Art. 3 regulates access according to three categories: 1) Records of general and public interest; 2) "Special documentations" requiring permission from a federal ministry in Baghdad which is content- related competent; and 3) Classified documents that are only accessible to state officials who have special training and serve the security interests of the federal government. Moreover, Art 4 of the law includes the following two clauses: 4.1) Scientists, students and members of the media can apply for access at a content-related competent federal ministry in Baghdad; and 4.2) Applications to 
gain access to records of former governments that document crimes against humanity must be submitted at the federal Ministry of Culture in Baghdad, subject to the approval of the Iraqi government's Council of Ministers. The 2016 law, however, does not provide for the establishment of a specific "permanent Iraqi archive" pursuant to the accountability and justice legislation adopted in 2008.

Iraq's applicable federal law and regulations regarding both the Kurdish Anfāl files and the Ba'athist regime records remain unclear given these differing legislative outcomes in Iraqi Kurdistan and Baghdad. The Iraqi federal government failed to fully implement the provisions of the 2008 Accountability and Justice Law No. 10, which called for it to assume temporary responsibility of all former Ba'athist regime files until "a permanent Iraqi archive" (institution) could be established "pursuant to the law." This provision still awaits implementation.

The Kurdish parliament's failure to adopt legislation governing the Anfāl files and other records begs the question whether they should be considered part of the overall Saddam regime records under the control of the Federal Republic of Iraq in Baghdad, subject to the laws passed in 2008 and 2016 asserting oversight of the Ba'athist records. Such a decree, however, would ignore the provenance of the documents, their significance to Kurdish memory and history, and their longstanding recognition as Kurdish patrimony. The Kurdish seizure of the files in 1991 predated by more than a decade the overthrow of Saddam's regime in the 2003 U.S. invasion and the creation of the majority Shiite government in Baghdad. By this time, Kurdish claims over the documents had already been long established and acknowledged by international parties. This recognition served as the basis for the U.S.-Kurdish agreements providing for the various transfers of the original Anfāl files to the U.S. for analysis of the human rights crimes committed by Saddam' security forces in Iraqi Kurdistan. Among other things, these agreements pledged the return of the documents to the Kurds upon request in recognition that ownership resided with the Kurds and that they comprised a critically important part of the historical patrimony of the Kurdis$\tan$ region.

Saddam had initially alleged that the seized files were forgeries, which HRW dispelled in its analysis of the documents in the early 1990s. Thereafter, Saddam abandoned the documents to the Kurds lest efforts to reclaim them be seen as authenticating the files and incriminate his regime for the crimes of Anfāl. It should also be noted that international law does not prohibit the capture of state security documents by anti-government forces in an uprising aimed at securing their own liberation and survival from a genocidal regime, nor their transfer to an outside foreign power.

Human rights NGOs also recognized the vital importance of the files as an inextricable and indisputable part of Kurdish history, captured in a rebellion for liberation against a genocidal dictator. The Middle East division of Human Rights Watch became involved in the discussions with the Kurds to transfer the documents to the U.S., following the lead of Peter Galbraith of the U.S. Senate 
Foreign Relations Committee (Montgomery, 2019: pp. 48-52). Galbraith was responsible for negotiating the agreements with the Kurds-recognizing their ownership-as well as securing Pentagon funding to airlift the files to the U.S. The documents comprised an unprecedented windfall of evidence against a homicidal regime still in power and held the possibility of hauling Saddam and his henchmen before an international tribunal for their crimes. The international community, moreover, has never contested Kurdish ownership of the files, acknowledging them as the historical patrimony of the Kurds.

Thus, two sets of ownership rights govern the records of the former Saddam regime: 1) the Kurdish Anfäl files that have long belonged to the Kurdish people of Iraq, predating the creation of the post-Saddam order in Baghdad; and 2) all other Ba'athist records overseen by the federal government in Baghdad on behalf of the Iraqi people. Given the provenance of the Anfāl files, they should not be construed to be covered under the 2008 Accountability and Justice Law, which requires the turning over of all Saddam regime records into the temporary custody of the federal government in Baghdad until a "permanent Iraqi archive" (or equivalent) can be created "pursuant to the law." As already noted, such a scenario would violate the Iraqi Kurds' ownership rights of the Anfāl files, recognized by the U.S.-Kurdish agreement and implicitly acknowledged by the international community. Moreover, the 2005 Iraqi constitution anchors the political reality that among all the peoples of the federal republic, only the Iraqi Kurds have successfully opted for their own regional parliamentary system-the Parliament of the Kurdistan Region-in Erbil. In short, although the Kurdish regional parliament has yet to pass legislation governing the Anfāl files, the documents remain the property of the Kurds to decide their ultimate disposition and use. Neither Iraqi law nor any international agreements involving the U.S. or other foreign governments would reasonably oblige the Iraqi Kurds to cede the Anfāl files to the central government, which currently holds the majority of the originals at the tribunal in Baghdad.

Further, the Kurdish parliament will have to decide whether it will renew efforts to enact legislation governing the digital files and the small assortment of originals in Kurdish possession, as well as the majority of the originals that have yet to be retrieved from the tribunal in Baghdad. If not, the Kurds will be left both without a separate legal provision regulating access and use of the Anfāl files as well as a special, dedicated institution to house and preserve them. Nonetheless, it is conceivable that the Council of Representatives in Baghdad could adopt a law establishing "a permanent Iraqi archive" (institution) under the provisions of the 2008 Accountability and Justice Law No. 10. Should this occur, it may be assumed that such a "permanent Iraqi archive" seated in Baghdad would house primarily the sources of the former Ba'ath Regime, leaving the Kurds to continue housing the Anfāl files at their temporary custodian archive-the Zheen Archive Center in Sulaimaniyah-until they establish a permanent regional Kurdish records institution. The Kurds should consider adopting a sepa- 
rate KRI/KRG law and institution modelled on the German Stasi archives, which administers the classified secret police files of the former East German government. This German authority aims above all at national reconciliation, forgiveness, and transparency relating to the past crimes and activities of the former East German police state.

In brief, the only Iraqi authority empowered to grant access to the files of Saddam's Ba'ath regime is presently the Council of Ministers of the federal government of Iraq in Baghdad. Currently, applications for access to the files must be submitted in writing to a content-related federal ministry. Whereas in the Kurdistan Region of Iraq, the Zheen Archive Center continues to function as the temporary custodian of all the Kurdish Saddam regime collections until the Regional Parliament in Erbil decides otherwise and perhaps passes its own legal regulations within the framework of the 2005 Iraqi constitution-ensuring against the misuse of the Anfāl files for wrongful convictions by recognizing the general principle that all citizens must be considered innocent unless proven guilty by an independent court in a fair trial. Finally, it is hoped that U.S. archives and institutions-collectively holding tens of millions of digitized documents from Saddam's dictatorial rule-will recognize and honor Iraq's legal situation regarding both the Kurdish Anfāl files and the Saddam regime's Ba'ath documents. This might involve, for example, coordinating policies regulating access and protecting personal identifying information contained in the files.

\section{Social-Political Impact of Repatriating the Saddam Regime Files to Iraq}

The restitution of the digital Anfäl files to the legitimate representatives of the Iraqi Kurds and the captured records of Saddam's regime to the majority Shiite government in Baghdad has produced mixed results. Both restitution cases have been complex, involving severe challenges and problems. The U.S. repatriation of the vast trove of records seized in the 2003 war into the hands of Fayyad, Iraqi Prime Minister Maliki's national security adviser, and his pro-Iranian security services on May 16, 2013, promised their malign exploitation against the perceived enemies of the majority Shiite regime (Montgomery, 2019: p. 201). The repatriated documents were evidently not used to foster reconciliation or democratic and social reform, but rather to purge former Sunni officials of Saddam's regime from government institutions. The files may also have been exploited against the leaders of the 2013-2014 Sunni protest movement in the provinces-violently confronted by Maliki's security forces-that soon attracted Sunni militants, helping to fuel the rise of the ISIS terror group. The background and details of the misuse of the files are not yet fully known. U.S. officials understood the potential consequences of repatriating the politically poisonous files to Maliki's growing sectarian and authoritarian government. Nevertheless, Pentagon budget cuts impelled the closing of the media processing and storage facility in Qatar and returning the seized records to Baghdad. Defense officials also rea- 
soned that the U.S. military no longer needed the original files after the 2011 withdraw of U.S. troops from Iraq and that it was time for the Iraqi government to handle its own affairs. Commenting on the repatriation, one State Department official stated, "We decided that at a certain point, a country has to handle its own affairs and we needed to treat the Iraqis like adults. If the Iraqis were going to kill each other, they were going to kill each other"6 (Montgomery, 2019: p. 201).

For their part, the Sunni groups have repeatedly protested being purged from power and sidelined in the democratic Parliamentary process, exacerbating sectarian divisions in the country. In reaction to Iraq's lack of national reconciliation and democratic power-sharing, the geopolitical power struggle for a new post-colonial order of Eurasia and the Middle East has escalated dramatically. The power struggle has been increasingly dominated by regional players-Arabs, Iranians (Persians) and Turks under irreconcilably, rivaling Islamic religious motivated agendas, with little prospect for future compromise. It has also triggered a renewed asymmetric, irregular warfare based on stooges, militias, and mercenaries, which have waged war under a variety of labels, notably ISIS, ISIL or Daesh. They first managed to further destabilize Iraq and war-torn Syria, bringing both states on the brink of collapse. They ultimately failed to force regime change in Baghdad and establish their own medieval style "Caliphate" state modelled on a barbaric distortion of Islam. However, it has to be stressed, that ISIS \& Co. have neither been defeated nor wiped out given that they still maintain a network of contacts and bases-including in the internment camps-in Syria and Iraq. They also have at their command a substantial number of sleeper cells in the Middle East and the West. Further, they continue to receive financial, logistic, and military support from foreign powers, attracting more of the disaffected young, in particular the unemployed and hopeless-the abandoned outsiders and outcasts from various societies.

At the same time, the renewed, escalating violent protests notably in Baghdad against the government's endemic corruption, enrichment of a small elite, mismanagement, lack of reforms, and paralysis of society, again show an ever-increasing demand for fundamental change and reform beyond the political and religious camps in Iraq. Iraq's current socio-political plight demonstrates that its fundamental restructuring requires first coming to terms with its past to better manage a radical transformation away from oligarchs, warlords, and stooges of foreign powers-emerging out of a toppled Gulag regime-to politicians, parliamentarians, and democrats who are answerable to the public. To use the available archives of a failed, corrupt, and brutal past as a catalyst for badly needed reform would have been one option to help reconcile and stabilize Iraq. So far, this option has not been pursued.

Instead, the majority Shiite government appears to have exploited the former

${ }^{6}$ Bruce P. Montgomery and Michael P. Brill, “The Obama Administration's 2013 Repatriation of the Iraqi State Files" (manuscript in progress). This quotation was derived from Brill's interview with a State Department official. 
Ba'ath regime archives for vengeance in the ongoing de-Ba'athification process in Iraq. The de-Ba'athification process began in May 2003 to oust the former ruling Sunni Ba'ath elite from power, disband the Iraqi army and security services, and establish a new central power structure in Baghdad. ${ }^{7}$ The ruling power structure is still dominated by Iran, increasingly based on its transnational military proxy-militia networks determined by the Islamic Republic. ${ }^{8}$ Iraq's national de-Baathification policy was chiefly designed by the late ambivalent Shia-politician Ahmed al-Chalabi (1944-2015) and the Iraqi National Congress (INC), which he co-founded. Chalabi and the INC managed to convince U.S. officials that most of the Iraqi Sunni Ba'ath regime should be indiscriminately removed from office and banned from returning to power. Nevertheless, the U.S. based the de-Ba'athification policy on its "de-Nazification" strategy ${ }^{9}$ fter WWII. ${ }^{10}$

After the 2003 U.S. invasion of Iraq, officials in the George W. Bush administration differed on how to deal with members of the overthrown Ba'ath regime. (Diamond, 2005; Chandrasekaran, 2006: pp. 79-80; Crane \& Terrill, 2003: pp. 13-15). The U.S. Defense Department urged an extensive purging of all former members of the Ba'ath Party. In contrast, the State Department and CIA argued for a constrained "de-Saddamification" policy to specifically target former Ba'ath leaders guilty of crimes. A compromise was proposed (but not carried out) providing for the removal of Ba'athist leaders while leaving lower ranking party members to face a "Truth and Reconciliation Commission" similar to the South African proceedings (Chandrasekaran, 2006: p. 79).

In the end, in 2003, the Administrator of the Coalition Provisional Authority (CPA), Paul Bremmer III, decreed two fateful de-Ba'athification orders shortly ${ }^{7}$ Coalition Provisional Authority: CPA/ORD/16 May 2003/01:

http://www.iraqcoalition.org/regulations/20030516_CPAORD_1_De-Ba_athification_of_Iraqi_Socie ty_.pdf; 20030823_CPAORD_2_Dissolution of_Entities_with_Annex_A:

http://iraqcoalition.org/regulations/20030823 CPAORD 2 Dissolution of Entities with Annex A .pdf (both retrieved 29 Dec. 2019 successfully, but since then not available online).

${ }^{8}$ Iran's security intelligence commander, Qassem Suleimani, 62, was killed early Friday, January 3, 2020, in a missile strike by an American MQ-9 Reaper drone near Baghdad International Airport that was authorized by President Trump:

https://www.defense.gov/Newsroom/Releases/Release/Article/2049534/statement-by-the-departmen t-of-defense/ (retrieved 3 Nov. 2020). Maj. Gen. Suleimani led the powerful Quds Force of the Islamic Revolutionary Guards Corps. The strike killed five people, among them the pro-Iranian militia chief Abu Mahdi al-Muhandis, 66, head of the Popular Mobilization Committee, an umbrella group for pro-Iranian Iraqi militias. For current background information see: Tim Arango, James Risen, Farnaz Fassihi, Ronen Bergman and Murtaza Hussain (2019a). A Spy Complex Revealed. Leaked Iranian Intelligence Reports Expose Tehran's Vast Web of Influence in Iraq. The Intercept in partnership with The New York Times. November 18 2019:

https://theintercept.com/2019/11/18/iran-iraq-spy-cables/; Arango The New York Times: The Iran Cables: Secret Documents Show How Tehran Wields Power in Iraq, Nov. 18, 2019b:

https://www.nytimes.com/interactive/2019/11/18/world/middleeast/iran-iraq-spy-cables.html (both retrieved the same day).

${ }^{9}$ Crane \& Terrill, 2003: pp. 13-15; White, 2003, Policy Watch 715, February 25, 2003.

${ }^{10}$ Military Government of Germany (1945). Directive to the Commander in Chief of the United States Forces of Occupation. The Department of State Bulletin, Vol. XIII, No. 330, Publication 2405, October 21, 1945, Washington: Office of Public Communication, Bureau of Public Affairs, pp. 596-607; see further 1945 Bulletins: June 10, 1945, p. 1051; August 19, 1945, p. 275; November 25, 1945, pp. 841-849, 843, 847-848; December 2, 1945, pp. 885-892. 
after his arrival in Baghdad. CPA order no. 1 terminated Ba'athist public sector employees from their positions and banned them from future public employment. The second order, CPA order no. 2, disbanded the military and security and intelligence infrastructure of Saddam's regime, stripping tens of thousands of former military and security personnel of their jobs, pay, and status-seeding future mass violence against the new order. Bremmer's de-Ba'athification orders received considerable criticism for going too far. ${ }^{11}$ Not only did they fail to discriminate between innocent and criminal former Ba'ath members, but de-Ba'athification was aimed primarily at the upper leadership of the overthrown Saddam Hussein regime. The Sunnis targeted under the de-Ba'athification process accused their persecutors of an indiscriminate "de-Sunnification" of Iraq, victimizing innocent citizens, permanently disempowering Sunni elites, turning over control of Iraq to the Shiites and pro-Iranian proxy militias, and altering an ever delicate balance of power in the region (Ricks, 2006: p. 437 quoting Amin Saikal, then Director of the Center for Arab and Islamic Studies at the Australian National University in Canberra, who warned against "a devastating impact on the region and beyond").

The "de-Ba'athification" process remains ongoing after undergoing several revisions (Sissons \& Al-Saiedi 2013: p. 2). The cleansing of Sunnis from power not only ignited Iraq's insurgency during the U.S. occupation (Ferguson, 2008: p. 184; Hendrickson \& Tucker, 2005: p. 2, 6, 19), but also incited the rise of terror groups like ISIS in Iraq and beyond (Thompson, 2015, TIME, May 29, 2015; Zinn, 2016: p. 9/2; Oosterveld \& Bloem, 2017: p. 1-23, 19). These violent forces escalated during the sectarian-driven government of Shia-Premier Nouri al-Maliki (2006-2014) into an Iraqi Civil War (2014-2017). Whatever the final results of the ongoing de-Ba'athification process, one interim outcome has already become apparent regarding contemporary Near East "realpolitik." Approximately 700 pages of documents from Iran's Ministry of Intelligence and Security, dating between 2014 and 2015, were publicly leaked, detailing Iran's covert operations in Iraq. So far, the documents reveal at least one decisive consequence of "de-Sunnification" - that dismissed former Iraqi security and military officers who had worked as long-serving spies for the CIA sold their services as well as classified information to Iran and switched sides to ally themselves with the Islamic Republic. This has facilitated the Islamic Republic's efforts to subjugate Iraq as an "Iranian-controlled satrapy" based on the Shia proxy-militia Hezbollah model in

\footnotetext{
${ }^{11}$ Selective examples: Early warnings to distinguish between guilty and innocent: Rabil, 2002: pp. 1-14; 2003: pp. 38-50; 2004 (Walid Phares). De-Bathification Went too Far. 5 March 2004: ICG International Crisis Group, Middle East Briefings \& Reports, 2003a, 2003b, 2008a, 2008b, 2013; Saghieh, 2007: pp. 203-223; further reading: Ricks, 2006: pp. 440-451: "Fiasco"; Pfiffner (2010). US Blunders in Iraq: De-Ba'athification and Disbanding the Army. 76-85; Sissons \& Al-Saiedi 2013: p. 1-2, 9: "Bitter legacy; large-scale, politically based dismissals; without accurate data; dismissed people based on rank, not behavior; a deeply flawed process; widely criticized as inadequate, inefficient, and unrealistic; ineffective and incoherent, it polarized Iraqi politics and contributed to severe instability in the Iraqi military and government; The overriding goal of de-Ba'athification was to prevent the Ba'ath Party from returning to power in Iraq." See also Nakash, 2003.
} 
Lebanon (Jonathan Spyer 2017'2; see also Hennerbichler 2018/I: 190).

The scale of Iraq's "de-Ba'athification" still cannot be quantified because of the scarcity of hard facts (Sissons \& Al-Saiedi 2013: p. 1). However, the following data are credible based on a number of sources. These include the CPA's reported accomplishments in 2003 and 2004, the 2012 study of Saddam Hussein's Ba'ath Party by Joseph Sassoon, Professor of History and Political Economy at Georgetown University, and the comprehensive research performed by Sissons and Saiedi (ICJT) in 2013. Based on these sources, several estimates, calculations, and hard facts can be asserted:

1) Status of Ba'ath Party members in 2002: According to Sassoon, in 2002, the archives of the Ba'th Arab Socialist Party Regional Command documents a total of 3,971,762 members. Out of these were 223,622 "active" and 45,537 "division members", led by 76 "Bureau Members or Secretary Generals" (Sassoon, 2012: p. 52).

2) In a January 1, 2020, email conversation, Sassoon explained: "There are no full and detailed statistics by ethnicity. The Ba'th Archives divided members by religion: Moslems and Christians and whether they were Arabs, or Kurds." Asked whether the majority (over 51\%) were Sunnis in 2002, Sassoon confirmed this as "probably right," but emphasized: "it would be a big mistake to think that the Shiis were not part of the Party or that they did not occupy senior posts."

3) Dismissals of military and security personnel: "At the stroke of a pen in May 2003, some 400,000 conscripts, officials, officers, and others were left unemployed by CPA Order 2." However, "many" of these people were reabsorbed into the new military and security institutions, but the precise numbers have not yet been established (CPA/ORD/23 May 2003/02; and Sissons \& Al-Saiedi [ICJT] 2013: p. 21).

4) Dismissal of Iraqi civil service employees: Estimated dismissals range from 900,000 to more than a million Iraqi civil servants, not counting the military. Approximately 45,111 civil service employees had been senior party members. Most were dismissed between 2003-2005 (except for 17\% in 2005). From 2004 to early 2006, at least 9088 people were reinstated. In 2008, some 41,000 new claims were filed for re-employment. By September 2011, a total of 6827 were reinstated (roughly 4110 "Udw Firqah" [Group] level members as well as 2717 "Udw Shu'bah" [Section] members). In addition, about 1257 former security employees were granted retirement with pensions. Therefore, since 2004 there have been 17,172 civil servants reinstated (2004-2006: 9088; 2008: 6827; 1257 retirements with pension). In sum: out of 45,111 civil servants who were initially sacked, some 17,172 were reinstated by 2011 . This brings the total number of dismissed civil servants to approximately 27,939 (CPA/ORD/16 May 2003/01; Sissons \& Al-Saiedi [ICJT] 2013: pp. 21-24, partly based on the CPA Accomplishments 2003-2004 Historic Review of 2004, pp. 1-71).

${ }^{12}$ Spyer, J. (2017): The Fall of Kirkuk: Made in Iran. The American Interest, published on October 18, 2017: https://www.the-american-interest.com/2017/10/18/fall-kirkuk-made-iran/ (retrieved 1 January 2020). 
The available data therefore indicates that the vast majority of dismissed former Ba'ath Party members comprised military and security personnel, which fueled the subsequent Sunni insurgencies against the new Shiite dominated order. At the same time, hard figures regarding dismissed and reinstituted Iraqi officers and soldiers remain unknown; their real number may be under the estimated 300,000 to 500,000 figure. As for Iraqi civil servants, available data indicate that roughly half of the 45,111 employees with a senior Ba'ath Party background were permanently removed from office.

\section{The Weaponization of Archives Backfires}

The U.S. restitution of the files, seized in the 2003 war, came amid Prime Minister Maliki's purges of Sunnis from power and violent crackdown against the growing Sunni anti-government protests in the provinces that fueled the rise of ISIS and the outbreak of civil war in 2014. Sissons and Saiedi reference the role of leading Iraqi Shia politicians like Ahmed al-Chalabi and other newly appointed ministers in Baghdad in pushing for the mass dismissals-a policy that accorded with Iranian interests to exert influence over the new majority Shiite political order in Iraq (Sissons and Al-Saiedi [ICJT], 2013: p. 12). According to Israeli analysts, the "real coup for Iran" has involved its success in penetrating Iraq's institutions at all levels. By late 2014, Iran already possessed lists of former Ba'athist officials and was exploiting the files to its advantage. ${ }^{13}$

Nonetheless, there are no current indications that the repatriated Saddam regime files are being stored securely in an Iraqi public archive institution. Such a scenario would have been highly unlikely given that the U.S. returned the seized documents directly into the hands of Iraq's security services. Rather, it may be assumed that the majority of the incriminating files are now under the control of Iraq's dominant Shia political and militia groups, likely scattered at various sites around the Baghdad metropolitan area. Given that Maliki's national security adviser led the restitution discussions with U.S. officials and oversaw the return of the Saddam regime files to Iraq, there was little chance that the documents would be housed and made publicly accessible at the Iraqi National Library and Archives. Iraq's security and intelligence services, largely under the sway of the pro-Iranian Shiite militias, have had no interest in making the files available to scholars and researchers instead of exploiting the trove of intelligence against the Sunni elites. Moreover, the Iraqi Library and Archives has long been politically marginalized and cast into a disorganized state after it was rebuilt with international assistance after the 2003 war. Instead, the various Iraqi warlord groupsthe Shia militias-seem to have taken collections of the incriminating files with the aim of using them as political ammunition against adversaries. If this proves correct, it may be anticipated that the misuse of these files for political warfare

\footnotetext{
${ }^{13}$ Frantzman, S.J. (2019). Iran Intel leak: 700 documents show how Iran outplayed the US in Iraq. The Jerusalem Post, November 18, 2019:

https://www.jpost.com/Middle-East/Iran-Intel-leak-700-documents-show-how-Iran-outplayed-theUS-in-Iraq-608183 (retrieved the same day).
} 
aimed at smearing opponents, settling scores, blackmailing, or taking revenge will continue to undermine efforts at national reconciliation and democratic reform to stabilize Iraq.

The current socio-political situation surrounding the Kurdish (digital) Anfāl files in Iraqi Kurdistan also remains on the brink of war and peace, albeit the circumstances differ considerably from Baghdad. A consensus regarding how to address the files according to the rule of law currently remains beyond reach. Neither the Kurdistan region nor the Iraqi Federal Republic have demonstrated any interest in coming to terms with the past and administering their respective collections of Saddam regime files along the lines of the German model in governing the Stasi archives of the former German Democratic Republic. Yet, this reckoning would seem necessary for the survival of Iraq as a constitutional democracy as well as its sovereignty and territorial integrity. If the Iraqi Kurds follow the self-destructive path in extrajuridially exploiting the Anfāl files against each other, it may well result in inciting a new internal civil war. This outcome would foster more division and weaken Iraqi Kurdistan, leaving the region open to further malignant foreign influence and subjugation.

To understand the social-political consequences of the repatriated Anfäl files on the Kurdistan Region of Iraq, it is important to recall who received and still retains the original (digitized) documents. First, the question of rightful ownership of the Kurdish "Anfāl" files was again addressed in 1997 between the US Senate Foreign Relations Committee and the main Iraqi Kurdish coalition partners, the KDP under Massoud Barzani and the PUK under Jalal Talabani. Upon the transfer of the files, authorized by the U.S. Senate Foreign Relations Committee, to CU-Boulder, Senate committee chair-Senators Jessie Helms-acknowledged in a June 1997 letter to Prof. Bruce P. Montgomery that not only did the files belong to the Iraqi Kurds, but that any request for their return must be honored (Montgomery, 2001: p. 79). Delegates of the KDP and PUK consented to this arrangement, acting in the role of overseers or custodians representing the majority will of the Kurdish people of Iraq.

Second, the Senate Foreign Relations Committee further recognized Kurdish rights to the Anfäl files when, in 1998, it provided copies of the database on 176 CD ROMS to the KDP and PUK (Sassoon \& Brill, 2020, quoting Joost Hiltermann, forthcoming; Montgomery, 2001: p. 79 cf.). Nevertheless, both parties kept their respective copies of the Anfāl database under their confidential control, rather than make them public to the Kurdish people subject to legal provisions governing their use. In brief, neither party made the databases available to other Iraqi Kurdish political groups, nor did they turn over copies to the regional democratic sovereign of the Kurdish people of Iraq, the KRI Parliament in Erbil and its democratically elected representatives.

These circumstances fueled an internal debate, which continues to be highly charged, about the role of political parties and the rule of law in a Parliamentarian democracy. In addition, it seems that the KDP and PUK may have withheld 
some of the original paper files from the 1991 uprising, rather than transferring them to the U.S. for analysis regarding the crimes of the Anfāl (Sassoon \& Brill, 2020). The quantity of files withheld by the Iraqi Kurdish parties remains publicly unknown. Hassan Mneimneh, co-director of the Iraq Research and Documentation Project (IRDP) at the time, stated that, "the documents that are missing [in possession of KDP and PUK Iraq] tend to be interesting documents," 14 most likely relating to informants. Surprisingly, the leading academic institution harboring the digitized Kurdish files in the U.S., the CU Boulder Archives, received no requests from external academic researchers to use the records for an extended period of time between 1998 and 2003 (Montgomery, 2019, verbal conversation). Nevertheless, the documents were consulted during this time by human rights NGOs, including the U.K.-based INDICT campaign, seeking to compile evidence to bring Saddam and his top henchmen to justice before an international tribunal like Nuremberg.

Third, the KDP and PUK came under criticism for secretly monopolizing the Anfāl files, prompting oppositional groups to conduct their own research into the documents. The emerging Kurdish "Gorran" (Change) movement, founded by the late Nawshirwan Mustafa (1944-2017), also sent researchers to the U.S. to examine the available digital records. Deputies of the Goran movement later helped initiate the failed effort in 2014 to enact a special regional law governing the documents in the Parliament of the Kurdistan Region.

Fourth, in September 2014, the CU-Boulder Archives under Prof. Montgomery's stewardship repatriated a copy of the digitized Anfäl files "openly and in an official ceremony" to the Kurdish people of Iraq (Sassoon \& Brill, 2020). Acting as an independent mediator, Professor Hennerbichler initiated negotiations for the digital files in 2012 with two goals in mind: 1) to help prevent the outbreak of new armed hostilities in the event the Anfāl and Ba'ath files were exploited outside the rule of law against political opponents; and 2) to promote reconciliation among both the Kurds and the various peoples of Iraq. According to Professor Hennerbichler, "one of our main concerns" in commencing discussions with CU-Boulder to obtain a copy of the Anfäl digital files for the Iraqi Kurds "was, that we wanted to end the practice of using the files in the possession of certain political parties against opponents and by that triggering new unrest, internal fighting, renewed bloodshed and in a worst case scenario a new civil war." ${ }^{15}$ Instead, as a result of the Hennerbichler/Montgomery discussions, the digital Anfāl files were deliberately and for the first time officially returned to the sole owner of the files, the Kurdish people of Iraq and its democratically legitimate representatives. Further, this transaction presented new opportunities to use the

\footnotetext{
${ }^{14}$ Sassoon \& Brill, 2020, quoting Mneimneh; see also Human Rights Watch (1993): Genocide in Iraq. The Anfāl Campaign against the Kurds. A Middle East Watch Report;

https://www.hrw.org/reports/1993/iraqAnfāl/; cf. also Human Rights Watch 1992, note: in 1998 CU Boulder, IRDP as well as KDP and PUK Iraq got 176 CD-ROMs of the mentioned digitized Kurdish "Anfāl” files.

${ }^{15}$ Email from Ferdinand Hennerbichler to Bruce P. Montgomery, May 18, 2020. Prof. Hennerbichler has numerous years of experience with the Kurds in the Kurdistan Region of Iraq.
} 
files for research, democratic reform, and reconciliation.

Fifth, the original Anfāl files, seized in the 1991 Kurdish uprising, remain unavailable at the Iraqi High Tribunal (IHT) in Baghdad-now the renamed Supreme Iraqi Tribunal. In the 2005 transfer of the 18 metric tons of files to Baghdad for the trials of Saddam, Majid, and others, fifty-two boxes were inadvertently left behind at CU Boulder. These boxes were later returned to Iraqi Kurdistan in June 2019 in keeping with the KDP and PUK custodial agreements with the Senate Foreign Relations Committee. Nevertheless, it is unclear, what remains of the Anfāl documents after they were provided to the IHT. According to verbal communications with Iraqi security officials familiar with the fate of the files, several Shia groups confiscated the most important documents, while some records of lesser importance were dumped in loose containers on the streets of Baghdad.

Nonetheless, former and leading Kurdish officials confirm having seen the files, most notably the former director of the Iraq National Library and Archives in Baghdad, Saad Eskander. Furthermore, two Kurdish judges who presided over the trial of Saddam Hussein, Rizgar Mohammed Amin and Aso Mohammed Sofi, attested that these Kurdish Anfāl records contained "important evidence" incriminating the defendants. Although Saddam's 2006 trial for the crimes of the Anfāl was interrupted and he was rushed to the gallows for another crime-the Dujail massacre-the evidence of genocide was overwhelming. As Prof. Montgomery stated: "the Anfāl records by themselves did not include a 'smoking gun' document(s) and did not constitute sufficient evidence alone to convict Saddam Hussein. But the documents did serve as strong corroborating evidence in support of other medical-forensic evidence and survivor and witness testimonies sufficient to convict. In brief, taken together, this complete range of data comprised overwhelming evidence of genocide" (Montgomery, verbal conversation).

\section{Anonymous Accusations in "Facebook"}

In 2019, a group of Kurdish and European journalists, writers, and filmmakers, "committed to unbiased cross-party reporting," began exposing names, photographs, and other details involving Iraqi Kurds who allegedly collaborated with Saddam's Anfāl genocidal campaign against the Kurdish population in the late 1980s. The group comprising mostly freelancers, focusing on Kurdish questions in Turkey, Iran, Iraq, and Syria "not covered by mainstream media," was the first to post this incendiary information on the social media platform Facebook in Europe ${ }^{16}$ The group's anonymous authors posted lists of "all" alleged Kurdish military commanders who served in Saddam's Ba'athist army, labeling them "traitors," guilty of having "committed war crimes" "for Saddam Hussein." The

${ }^{16}$ https://www.facebook.com/901064556615607/photos/a.901092616612801/2126622697393114/?typ e=3\& theater (retrieved most recently 13 December 2019). Publication of a graph on "Facebook" is referenced for April 14, 2019, under a sub-section called "Kurdish Views", which is linked to the webpage kurdishquestion.com. Names of an originator, author or copyright holder are not given. The seat of the publication is not stated. 
social media posts also claimed that Saddam's former genocidal collaborators "are now" being "protected" by the three leading parties of the Kurdistan Region of Iraq.

One Facebook posting in German included a graph, containing "the list" of "Jash"- a derogatory term meaning "donkey's foal" or "traitor"-along with their names and photographs who allegedly were "involved in the Anfäl-operations" against their own people. The posting did not repeat the allegation that all of them had committed "war crimes." The graph also noted the "party- membership" of the accused, marked by different colors: out of 92 accused individuals who "live/lived" in the Kurdistan Region of Iraq, 80 were under the alleged protection of the KDP; 13, the PUK; and two, the Gorran. The authors do not state when the accused became members of these parties. The charge that the accused were party members "now protected in Kurdistan Region Iraq" "under the protection" of the KDP, PUK, and "Gorran," implies that these parties would prevent these purported war criminals from being tried and sentenced in court. Finally, the anonymous "authors" of the posting invited the public to share their comments on the captured text, eliciting 13 "likes."17

When asked whether the published incriminating material was based partly on the digital Anfāl files, a German speaking anonymous "author" first promised to do original research into the matter, but evaded the question. ${ }^{18}$ Indeed, credible sources for these allegations remain unclear-whether based on personal eyewitness accounts or Saddam's regime records with permissible, regulated access, or from both or other sources, or none at all. The postings name the "participation" of 92 Iraqi Kurds whose assumed identity is accompanied by their photographs. All of those named are alleged to have individually participated in the crimes of the Anfäl against their own people, including crimes against humanity and genocide. Nonetheless, such proof is neither provided nor indicated. Despite these allegations, the presumption of innocence should apply unless the accused are fairly tried and convicted by an independent court in accordance with international law.

The Facebook postings appear to be criticism by a young generation of Kurds both from Eurasia and the diaspora in Europe regarding the current prevailing crisis in Iraqi Kurdistan. The aim of the author(s) is to indicate that there is no rule of law and no independent juridical justice in the Kurdistan Region of Iraq. Further, that a number of publicly known, alleged Kurdish war criminals involved in the Anfāl genocide remain at large, unaccountable, and unpunished under the illegal protection of leading Iraqi Kurdish parties. Michael Brill, a Princeton graduate student in the Department of Near Eastern Studies, noted the irony of these events: All of this is kind of ironic in that it was the general amnesty offered by the KRG to the former Jahsh (many of which were sympathetic or infiltrated by the KDP and PUK) contributed to their mass defection ${ }^{17}$ Retrieved 13 December 2019.

${ }^{18}$ https://m.facebook.com/story/graphql_permalink/?graphql_id=UzpfSTkwMTA2NDU1NjYxNTY wNzoyMTI2N jMzODYwNzI1MzMx (retrieved 15 December 2019). 
from Saddam's regime during and after the 1991 uprising. In a sense, it offers an alternative example to de-Ba'thification. Sure, it was hardly a truth and reconciliation commission, but given the challenges facing Iraq's Kurds at the time, uncertainty about whether the U.S. and UN would continue to support them, etc., it certainly made sense to take as many men with guns and military/paramilitary training as possible." ${ }^{19}$

Although the criticism by Kurdish youth is not new and has often appeared in annual international human rights reports, it nevertheless indicates new trends in the Kurdistan region. ${ }^{20}$ Within Iraq's endemic cycles of social crises (Fantappie, 2019: pp. 1-7), the popular protests involving mostly Kurdish youth demanding sweeping democratic reforms are unique to the Kurdistan region. ${ }^{21}$ The extent of this social protest is markedly less violent than the mass popular unrest and ruthless crackdowns by the security forces, resulting in hundreds of killings, in the rest of Iraq. The last major protests that unsettled the Kurdistan region were in 2011. ${ }^{22}$ Despite its severe problems, Iraqi Kurdistan remains one of the most stable and secure regions in Eurasia and the Middle East. Nevertheless, the Iraqi Kurds continue to struggle with how to address the Anfāl files-whether to finally pass legislation governing use of the state security files with the aim of coming to terms with the atrocities of Saddam's regime and fostering reconciliation, or leaving them ungoverned and open for rival political parties to exploit the documents against each other. The later would mirror the majority Shiite government's sectarian exploitation of the repatriated Saddam regime files-returned to Baghdad amid the continuing de-Ba'athification purges and successive disempowerment of the Sunni elites.

\footnotetext{
${ }^{19}$ Communication from Michael P. Brill to Bruce P. Montgomery, June 3, 2020.

${ }^{20}$ Cf. e.g. Iraq 2018 Human Rights Report. U.S. Department of State, Bureau of Democracy, Human Rights and Labor. Washington, 03/2019, p. 64:

https://www.state.gov/reports/2018-country-reports-on-human-rights-practices/iraq. Refers to violations in Iraq and the KRI, including: unlawful or arbitrary killings by members of the security forces and non-state groups, forced disappearances, torture, restrictions on free expression, the press, and the internet, widespread official corruption, violence against and restrictions on women, violence against lesbian, gay, bisexual, transgender, and intersex (LGBTI) individuals and the effective criminalization of LGBTI status, violence against internally displaced persons (IDPs), and restrictions of worker rights. Impunity effectively existed for government officials and security forces personnel. Both Baghdad and Erbil conducted investigations into alleged abuses, but little was done to punish human rights violators. See response statement by Dindar Zebari, KRG Coordinator for International Advocacy, March 15, 2019: https://www.rudaw.net/english/ kurdistan/210520192: Accusations in the U.S. 2018 Human Rights Report "had already been addressed." Actions regarding freedom of press/expression "are taken in accordance with the law" and regulations of the Iraqi Penal Code. The "KRG has a strong willingness to enhance its governance practice and the situation of human rights in the Kurdistan Region in line with internationally-accepted standards." Further reading: HRW Human Rights Watch, World Report 2019, Iraq:

https://www.hrw.org/world-report/2019/country-chapters/iraq; UNIRAQ Human Rights Reports: http://www.uniraq.org/index.php?option=com_k2\&view=itemlist\&task=category\&id=164:human-ri ghts-reports\&Itemid=650\&lang=en (all links retrieved 14 December 2019).

${ }^{21}$ The youth represent the majority of the Iraqi Kurdish population. According to the census of May 2010 , they comprise more than $50 \%$ of Iraqi Kurds under the age of $20 ; 36 \%$ are 14 or younger and only $4 \%$ are over 63 .

${ }^{22}$ Hennerbichler 2012: https://www.hennerbichler.info/aufstaende-2011.html; 2018: 196, 211, 223; HRW World Report 2012: 560-566.
} 
In the 1990s, the older, ruling Kurdish generation fought and overcame an internal civil war, leading to the establishment of constitutional, federal self-rule of the autonomous Kurdistan Region of Iraq. Nevertheless, under the new political order, the Kurdish elites have become little more than oligarchs and warlords, exhibiting increasing authoritarianism centered in a booming urban gravity of power in Erbil. Kurdish sources indicate that these ruling elites continue to exploit the heritage archives of Iraqi Kurdistan, including the Anfäl records of the overthrown Ba'ath regime, to attack opponents and consolidate power. ${ }^{23}$ In sharp contrast and as a means of protest, younger Iraqi Kurds are increasingly using the global influence of social media platforms like Facebook to pressure the older ruling elites to adhere to the rule of law, enable an independents judiciary, bring alleged Kurdish criminals of contemporary history to justice, and free Kurdistan from the plague of oligarchs and warlords in favor of democratic majority rule.

Even so, the Facebook attacks against alleged Kurdish perpetuators in the Anfāl campaign are equally questionable on legal grounds. The published charges and denunciations are not supported by hard, verifiable evidence. The unsubstantiated postings could scarcely be used as evidence in a court of law, nor would they likely draw the attention of the world community or the Iraqi Kurdish ruling elites to initiate trials against the purported Anfāl war criminals. Rather, the public postings may be seen as a powerless plea for help to the international community with the aim of pressuring the ruling Iraqi Kurdish elites to bring to justice those alleged criminals of the contemporary past within their own ranks. Whatever the specific intentions behind the postings, they appear to demonstrate a demand for accountability, or otherwise a desire for punishment and imprisonment, if not revenge.

The social media postings may be seen in the broader context of the escalating protests and demonstrations carried out by reform-oriented youth not only in Iraq, but in the Middle East and Arab world. Moreover, virtually all the available polling and survey data in this part of the world, including Iraqi Kurdistan, verify the younger generation's decisive commitment to reform and social justice. The data also show a growing consciousness among all segments of Iraqi society that reconciliation represents the only way forward to ensure a viable and sustainable future for the Federal Republic and its survival. Further, these findings indicate a realization that a policy of reckoning with alleged criminal officials in the former Ba'athist regime would do more harm than good or undermine the implementation of humanitarian principles of peaceful coexistence, which have proved successful in reconstructing such post-authoritarian societies as South Africa ("Truth Commission") and in the reunification of Germany (GDR STASI Files law).

Nevertheless, based on the experiences of Germany and South Africa, it will likely take considerable time before a clear majority of the Iraqi people reach ${ }^{23}$ Hennerbichler discussions with long-standing Kurdish colleagues and contacts inside Iraqi Kurdistan. 
consensus that national reconciliation and forgiveness, instead of revenge and retribution, represent the only reasonable way forward. As a result, the internal socio-political dynamics in both Iraqi Kurdistan and federal Iraq are likely to keep them on the brink between reconciliation and renewed armed conflict. One means of measuring such progress, however, would involve tracking how the Kurdish regional government in Erbil and the majority Shiite government in Baghdad use or misuse the archives of the former Saddam regime.

Despite these socio-political challenges in the Kurdistan region of Iraq, there is a measure of hope that the Kurds can address them. Contemporary Kurdish history has been characterized by positive and negative extremes involving shifting alliances, battle lines and blurred borders. On the positive side, the Kurds' transformation from a marginalized and persecuted minority people in the $20^{\text {th }}$ century to important non-state actors in the $21^{\text {st }}$ century with international recognition has marked a milestone in Kurdish history (Bengio, 2017: p. 8). The Kurds managed a "transnational awakening—both political and armed" which has been accompanied by "deep change" in the "internationalizing of the Kurdish issue” (Ünver, 2016: p. 65; Bengio, 2017: p. 45; Tugdar \& Al, 2018: p. 228). The future of the Kurds is still a paradox: On the one hand, the Kurds remain internally divided and dependent on foreign powers, their tactics largely based on para-diplomacy, and their methods multiple in nature and sometimes mutually defeating. On the other, "Kurdistan has proved to be the most stable, pro-Western, and reliable partner of the US in the last two decades" (Bengio 2018: p. 6). Therefore, if the Iraqi Kurds can bridge their internal divisions, they should be sufficiently secure to handle the "Anfāl" files of the former Saddam regime according to the rule of law and peacefully initiate sweeping reforms as well as foster reconciliation.

\section{Conclusion}

The majority of the records and archives of Saddam's regime seized in the 1991 Kurdish uprising and the 2003 U.S.-led invasion of Iraq have been returned to Iraqi Kurdistan and the Federal Republic of Iraq. Although the Kurds received a complete copy of the Anfāl digital database and a small assortment of the original documents from $\mathrm{CU}$ Boulder, they have yet to see the return of the majority, remaining 18 metric-tons of original Anfāl documents, constituting their patrimony, currently housed at the Special Tribunal in Baghdad under the custody of the majority Shiite government. According to conversations with Iraqi security officials, some of the most important Anfāl files have been taken by Shia groups looking for exploitable information. Whether and to what extent these Shia groups have used the documents against selected Kurdish individuals named in the files remains unknown. Neither is it known whether the majority Shiite regime will agree to return what is left of the original files at the Tribunal in Baghdad to Iraqi Kurdistan, which would represent an important gesture of reconciliation by Baghdad. 
In response to concerns that rival Kurdish parties were secretly monopolizing and targeting political opponents named in the Anfāl database, given to them by the U.S. Defense Intelligence Agency in 1998, an independent Kurdish delegation was formed to visit CU-Boulder in 2014 to receive a copy of the digital files. The delegation aimed to make the digital files available publicly for the first time to enable Iraqi Kurdistan to come to terms with Saddam's murderous rule and foster transparency, internal reconciliation, and democratic reform. Nonetheless, sources in Iraqi Kurdistan indicate that the main Kurdish parties continue to exploit the files against political rivals, exacerbating intra-Kurdish tensions and undermining the rule of law in the Kurdistan Region of Iraq. The Kurdistan regional parliament has so far failed to pass legislation providing for a permanent institution to house and govern public access and use of the Anfāl files, leaving them in the temporary custody of the Zheen Archive in Sulaimaninyah. The failure to regulate the access and use of the files leaves them open for continued misuse to the detriment of Iraqi Kurdish society. In the meantime, the corruption of Erbil's ruling elites has provoked a growing backlash among Kurdish youth demanding sweeping democratic reforms. Other Kurdish youth in Europe has attacked the ruling parties on the social media platform, Facebook, for protecting alleged Anfāl collaborators among their ranks, although they have provided no evidence to substantiate their claims. The adoption of legislation regulating the Anfāl documents, both in their digital and original paper formats, has more than symbolic importance. Such legislation should be modelled on the highly successful law governing the Stasi archives in Germany. It would represent a unified vision in how the politically poisonous Anfäl documents should be addressed by Kurdish society. It also would promise to legally restrict or end, in the best of circumstances, their malign exploitation by members of the rival political parties. More important, passage of legislation governing public use of the Anfäl files would enable the Kurdish people to confront their shared tragic history, fostering a greater sense of unity and purpose.

The socio-political aftershocks of the 2013 repatriation of the millions of records and documents seized in the 2003 U.S.-led invasion of Iraq have produced more distressing results. The vast trove of seized Saddam regime files was delivered into the hands of Shiite Primer Minister Nouri al-Maliki's national security advisor and his pro-Iranian security services in May 2013. The timing of their restitution could not have been more inauspicious as Maliki was increasing his authoritarian grip on power, purging Sunnis from the government, seeding the intelligence and security services with Shiite loyalists, and violently confronting the anti-government Sunni protests in the provinces, fueling the rise of ISIS and the outbreak of renewed civil conflict. The return of Saddam's Ba'athist files presented Maliki and his security services, as well as his successors, with a trove of intelligence listing the names of thousands of former Ba'athist members, officials, and security and intelligence personnel-criminal and innocent alike-as well as informers, collaborators, and others. The documents could have been 
transferred to a civilian institution for study and research regarding the history of Ba'athist Iraq, enable the country to come to terms with its totalitarian past, and foster sectarian and societal reconciliation-this was the initial vision of several Iraqis as well as others in the international community-but the new order under the majority Shiite regime was more interested in vengeance and held other ideas for Saddam's state security and intelligence files. The Iraqi parliament in Baghdad passed legislation in 2008 ostensibly asserting control over the records of the former Ba'athist regime, including housing them in a separate and permanent archive institution, but the law remains to be fully implemented.

The repatriation of the Anfāl files and Saddam regime documents to the Kurdistan Region of Iraq and the Federal Republic of Iraq has therefore been less than benign. Rather than follow Germany's example in enacting legislation governing public use of the Stasi archives with the aim of coming to terms with its authoritarian past and embracing humanitarian values, the ruling political elites in Erbil and Baghdad have exploited the files against their political and sectarian enemies. This abuse of history has further heightened internal division and conflict in the Kurdistan region and the federal republic of Iraq. How Erbil and Baghdad respectively decide to address these archives of atrocity with the aim of confronting the past will indicate whether Iraq has a future as a democratic state or will remain mired in a continuing cycle of revenge and retribution.

Recent political developments in Iraq, however, offer new opportunities for using the Saddam regime documents to foster reconciliation and increased respect for human rights. The appointment of Iraq's new prime minister, Mustafa al-Kadhimi, the former human rights advocate and co-founder of the Iraq Memory Foundation (directing the IMF's oral history project, including interviews with survivors of the Anfāl campaign) presents the best hope yet for U.S. diplomats, human rights advocates, scholars, and other supporters in urging the return of the original Anfāl files to Kurdistan. The return of the documents in an official ceremony would represent a significant gesture of good will and reconciliation on the part of Baghdad to the Kurdish people of Iraq, recognizing their grievous suffering, including the Kurdish genocide, under Saddam's bloody regime. Together with the other Ba'ath documents repatriated to Iraq, joint efforts should be encouraged to study Iraq's authoritarian history among Iraq's Kurds, Sunnis, and Shiites, along with international scholars and institutions. These efforts would pave the way for the various peoples of Iraq to come to terms with their interrelated, tragic past in the spirt of promoting a greater sense of unity and nationhood. A shared understanding of Iraq's recent authoritarian past is one way for Iraqis to chart a democratic future based on human rights and the rule of law.

\section{Acknowledgements}

The authors extend special thanks to linguist, translator, and author Abdol 
Hamid Husseini, M.A., for his valuable assistance in researching and evaluating various Kurdish, Persian, and Arabic sources for this study.

\section{Conflicts of Interest}

The authors declare no conflicts of interest regarding the publication of this paper.

\section{References}

Arango, T., Risen, J., Fassihi, F., Bergman, R., \& Hussain, M. (2019a). A Spy Complex Revealed. Leaked Iranian Intelligence Reports Expose Tehran's Vast Web of Influence in Iraq. The Intercept, November 18, 2019.

https://theintercept.com/2019/11/18/iran-iraq-spy-cables

Arango, T., Risen, J., Fassihi, F., Bergman, R., \& Hussain, M. (2019b). The Iran Cables: Secret Documents Show How Tehran Wields Power in Iraq. The New York Times, Nov. 18, 2019.

https://www.nytimes.com/interactive/2019/11/18/world/middleeast/iran-iraq-spy-cable s.html

Bengio, O. (2017). The Kurds in a Volatile Middle East. The Begin-Sadat Center for Strategic Studies, Bar-Ilan University, Mideast Security and Policy Studies No. 130, Ramat Gan: Bar-Ilan, pp. 8-57.

Bengio, O. (2018). How Can the US Retin Stability in Post-Kurdish Referendum Iraq? In: SMA Reach-Back Report, 16 April 2018.

https://nsiteam.com/social/wp-content/uploads/2018/04/R6.8-KurdishIraq-Stability-FI NAL-24Apr17R.pdf

Bennet, B. (2006). Saddam Hussein Is Dead. Time, December 29, 2006.

http://content.time.com/world/article/0,8599,1573255,00.html

Chandrasekaran, R. (2006). Imperial Life in the Emerald City: Inside Iraq's Green Zone. New York: Vintage Books.

Chatham House (2008). The Iraqi Tribunal: The Post-Saddam Cases. https://www.chathamhouse.org/sites/files/chathamhouse/field/field document

Coalition Provisional Authority CPA (2003-2004). Regulations, Orders, Momoranda, Public Notices. http://www.iraqcoalition.org/regulations/index.html

Crane, C., \& Terrill, W. A. (2003). Reconstructing Iraq: Insights, Challenges, and Missions for Military Forces in a Post-Conflict Scenario. Carlisle, PA: U.S. Army War College, Strategic Studies Institute. https://doi.org/10.21236/ADA412663

Diamond, L. (2005). Squandered Victory: The American Occupation and the Bungled Effort to Bring Democracy to Iraq. New York: Owl Books.

Fantappie, M. (2019). Widespread Protests Point to Iraq's Cycle of Social Crisis (pp. 1-7). ICG International Crisis Group, 10 October 2019.

https://www.crisisgroup.org/middle-east-north-africa/gulf-and-arabian-peninsula/iraq /widespread-protests-point-iraqs-cycle-social-crisis

Ferguson, C. (2008). No End in Sight: Iraq’s Descent into Chaos. New York: Public Affairs.

Galbraith, P. W. (1992). Saddam's Documents. A Staff Report to the Committee on Foreign Relations, May 21, 1992 (pp. 1-11). Washington DC: United States Senate, Committee on Foreign Relations, Press Release.

Galbraith, P. W. (2007). “Chemical Ali” Didn't Act Alone. Los Angeles Times, June 28, 2007. https://www.latimes.com/la-oe-galbraith28jun28-story.html 
Galbraith, P.W. (2002). After Saddam, What? The Wild Card in a Post-Saddam Iraq. Boston Globe Magazine, December 15, 2002.

http://www.boston.com/globe/magazine/2002/1215/coverstory.html

Gellman, B., \& Randal, J. C. (1992). U.S. to Airlift Archive of Atrocities Out of Iraq. Washington Post, May 19, 1992.

https://www.washingtonpost.com/archive/politics/1992/05/19/us-to-airlift-archive-of-a trocities-out-of-iraq/f9791b28-6a6e-46f6-9a86-07e7f61bd725 (Access Needed)

Gordon, M. (2015). Archive of Captured Enemy Documents Closes. New York Times, June 21, 2015.

https://www.nytimes.com/2015/06/22/world/middleeast/archive-of-captured-terroristqaeda-hussein-documents-shuts-down.html

Hendrickson, D., \& Tucker, R. (2005). Revisions in Need of Revising: What Went Wrong in the Iraq War. Carlisle, PA: U.S. Army War College, Strategic Studies Institute. https://doi.org/10.1080/00396330500156537

Hennerbichler, F., \& Montgomery, B. P. (2015). U.S. Restitution of the Iraq Secret Police Files from Saddam Hussein's Regime Regarding the Kurds in Iraq. Advances in Anthropology, 5, 31-38. https://www.scirp.org/html/4-1590451 53898.htm https://doi.org/10.4236/aa.2015.51004

Hiltermann, J. (2000). Elusive Justice: Trying to Try Saddam. Middle East Report, No. 215, 32-35. https://www.jstor.org/stable/1520153 https://doi.org/10.2307/1520153

Horn, S. (1992). Documents Give Evidence of Atrocities against Iraqi Kurds. Paper, Audio, Film Records Disclose Torture Sessions and Executions, Christian Science Monitor, June 10, 1992.

HRW Human Rights Watch (1993). Genocide in Iraq. The Anfāl Campaign against the Kurds. A Middle East Watch Report. https://www.hrw.org/reports/1993/iraqAnfāl

HRW Human Rights Watch/Middle East (1994). Bureaucracy of Repression: The Iraqi Government in Its Own Words. https://www.hrw.org/reports/1994/iraq/TEXT.htm

HRW Human Rights Watch/Middle East and Physicians for Human Rights (1992). Unquiet Graves: The Search for the Disappeared in Iraqi Kurdistan. New York. https://www.hrw.org/reports/1992/iraq/iraq0292.pdf

ICG International Crisis Group (2003a). Baghdad: A Race against the Clock. Middle East Briefing No. 6, 11 June 2003.

https://web.archive.org/web/20101221183433/http://www.crisisgroup.org/en/regions/ $\underline{\text { mid- }}$

dle-east-north-africa/iraq-syria-lebanon/iraq/B006-baghdad-a-race-against-the-clock.a spx

ICG International Crisis Group (2003b). Governing Iraq. Report 17, August 25, 2003. https://www.crisisgroup.org/middle-east-north-africa/gulf-and-arabian-peninsula/iraq /governing-iraq

ICG International Crisis Group (2008a). Iraq after the Surge I: The New Sunni Landscape (p. 32). Middle East Report No. 74, 30 April 2008.

https://www.crisisgroup.org/middle-east-north-africa/gulf-and-arabian-peninsula/iraq /iraq-after-surge-i-new-sunni-landscape

ICG International Crisis Group (2008b). Iraq's Civil War, the Sadrists and the Surge (p. 25). Middle East Report No. 72, 7 February 2008.

https://www.crisisgroup.org/middle-east-north-africa/gulf-and-arabian-peninsula/iraq /iraq-s-civil-war-sadrists-and-surge

ICG International Crisis Group (2013). Make or Break: Iraq’s Sunnis and the State (p. 
35). Middle East Report No. 144, 14 August 2013.

https://www.crisisgroup.org/middle-east-north-africa/gulf-and-arabian-peninsula/iraq Lmake-or-break-iraq-s-sunnis-and-state

Military Government of Germany (1945). Directive to the Commander in Chief of the United States Forces of Occupation. The Department of State Bulletin, 13, 596-607.

Montgomery, B. P. (2001). The Iraqi Secret Police Files: A Documentary Record of the Anfāl Genocide. Archivaria, 52, 69-99.

http://journals.sfu.ca/archivar/index.php/archivaria/article/viewFile/12815/14023

Montgomery, B. P. (2010). Counterpoint. Returning Evidence to the Scene of the Crime: Why the Anfal Files Should Be Repatriated to Iraqi Kurdistan. Archivaria, 69, 143-171. https://archivaria.ca/index.php/archivaria/article/view/13264

Montgomery, B. P. (2011). Immortality in the Secret Police Files: The Iraq Memory Foundation and the Baath Party Archive. International Journal of Cultural Property, 18, 309-336. https://doi.org/10.1017/S094073911100018X

Montgomery, B. P. (2014). US Seizure, Exploitation, and Restitution of Saddam Hussein's Archive of Atrocity. Journal of American Studies, 48, 559-593.

https://doi.org/10.1017/S0021875813002004

Montgomery, B. P. (2019). The Seizure of Saddam Hussein's Archive of Atrocity. Lanham, MD: Lexington Books.

Montgomery, B. P., \& Brill, M. P. (2019). The Ghost of Past Wars Live on in Critical Archive, War on the Rocks.

https://warontherocks.com/2019/09/the-ghosts-of-past-wars-live-on-in-a-critical-archi ve

Nakash, Y. (2003). The Shi'is of Iraq (Revised ed.). Princeton, NJ: University Press.

Oosterveld, W. T., \& Bloem, W. (2017). The Rise and Fall of ISIS: From Evitability to Inevitability, Volatility and Friction in the Age of Disintermediation: HCSS StratMon Annual Report 2016/2017 (pp. 1-23, 19). Hague: The Hague Centre for Strategic Studies.

Pfiffner, J. P. (2010). US Blunders in Iraq: De-Ba'athification and Disbanding the Army. Intelligence and National Security, 25, 76-85.

https://doi.org/10.1080/02684521003588120

Rabil, R. G. (2002). The Iraqi Opposition's Evolution: From Conflict to Unity? Middle East Review of International Affairs, 6, 14. http://www.mafhoum.com/press4/ira114.htm

Rabil, R. G. (2003). The Making of Saddam's Executioners. A Manual of Oppression by Procedures - MERIA, 7, No. 1. https://web.archive.org/web/20030517113751/http://meria.idc.ac.il/journal/2003/issue1 lrabil.pdf

Raghaven, S. (2006). Saddam Hussein Is Put to Death. Washington Post, December 30, 2006.

https://www.washingtonpost.com/archive/politics/2006/12/30/saddam-hussein-is-put-t o-death-span-classbankheadformer-iraqi-president-hanged-before-dawn-in-baghdad-t o-divided-reactionspan/43cc1d3f-7389-407b-a474-a378b4e59c2c

Ricks, T. E. (2006). Fiasco: The American Military Adventure in Iraq. New York/London: Penguin.

Saghieh, H. (2007). The Life and Death of de-Ba'athification. Revue des mondes musulmans et de la Méditerranée, L'Irak en perspective, 117-118, 203-223.

https://journals.openedition.org/remmm/3451 
https://doi.org/10.4000/remmm.3451

Sassoon, J. (2012). Saddam Hussein's Ba'th Party: Inside an Authoritarian Regime. Cambridge: University Press. https://doi.org/10.1017/CBO9781139042949

Sassoon, J., \& Brill, M. (2020). The North Iraq Dataset (NIDS) Files: Northern Iraq under Bathist Rule, 1968-1991. Journal of Contemporary Iraq \& the Arab World, 14, 105-126. https://doi.org/10.1386/jciaw 00021 1

Sissons, M. \& Al-Saiedi, A. (2013). A Bitter Legacy: Lessons of De-Baathification in Iraq. International Center for Transitional Justice ICTJ, Report March 2013. https://www.ictj.org/sites/default/files/ICTJ-Report-Iraq-De-Baathification-2013-ENG. pdf

Thompson, M. (2015). How Disbanding the Iraqi Army Fueled ISIS. TIME, May 29, 2015. https://time.com/3900753/isis-iraq-syria-army-united-states-military

Tugdar, E. E., \& Al, S., Eds. (2018). Comparative Kurdish Politics in the Middle East. Actors, Ideas, and Interests. Cham (CH): Palgrave Macmillan.

Ünver, H. A. (2016). Schrödinger's Kurds: Transnational Kurdish Geopolitics in the Age of Shifting Borders. Journal of International Affairs, 69, 65-98.

White, J. (2003). Complicity in Iraq: How Deep? Policywatch 715. The Washington Institute for Near East Policy, February 25, 2003.

https://www.washingtoninstitute.org/policy-analysis/view/complicity-in-iraq-how-dee $\underline{p}$

Wilkinson, S. (2019). Who Owns These Records? Authority, Ownership, and CustodyofIraq's Baath Party Records. RBM: A Journal of Rare Books, Manuscripts, and Cultural Heritage, 20, No 1. https://rbm.acrl.org/index.php/rbm/article/view/17770/19582

Zinn, C. M. (2016). Consequences of Iraqi De-Ba'athification. Cornell International Affairs Review, 9. https://journals.library.cornell.edu/index.php/ciar/article/view/480 